\title{
The Soldier as "l"-Witness in Novels by Barbusse and Ehni
}

\author{
Jane E. Evans \\ University of Texas El Paso
}

Follow this and additional works at: https://docs.lib.purdue.edu/clcweb

Part of the Theatre and Performance Studies Commons

Dedicated to the dissemination of scholarly and professional information, Purdue University Press selects, develops, and distributes quality resources in several key subject areas for which its parent university is famous, including business, technology, health, veterinary medicine, and other selected disciplines in the humanities and sciences.

CLCWeb: Comparative Literature and Culture, the peer-reviewed, full-text, and open-access learned journal in the humanities and social sciences, publishes new scholarship following tenets of the discipline of comparative literature and the field of cultural studies designated as "comparative cultural studies." Publications in the journal are indexed in the Annual Bibliography of English Language and Literature (Chadwyck-Healey), the Arts and Humanities Citation Index (Thomson Reuters ISI), the Humanities Index (Wilson), Humanities International Complete (EBSCO), the International Bibliography of the Modern Language Association of America, and Scopus (Elsevier). The journal is affiliated with the Purdue University Press monograph series of Books in Comparative Cultural Studies. Contact: <clcweb@purdue.edu>

\section{Recommended Citation}

Evans, Jane E. "The Soldier as "I"-Witness in Novels by Barbusse and Ehni." CLCWeb: Comparative Literature and Culture 17.3 (2015): <https://doi.org/10.7771/1481-4374.2844>

This text has been double-blind peer reviewed by $2+1$ experts in the field.

The above text, published by Purdue University Press @P Purdue University, has been downloaded 265 times as of $11 /$ $07 / 19$.

This document has been made available through Purdue e-Pubs, a service of the Purdue University Libraries. Please contact epubs@purdue.edu for additional information.

This is an Open Access journal. This means that it uses a funding model that does not charge readers or their institutions for access. Readers may freely read, download, copy, distribute, print, search, or link to the full texts of articles. This journal is covered under the CC BY-NC-ND license. 


\title{
PURDUE
}

UNIVERSITY PRESS <http://www.thepress.purdue.edu>

\section{CLCWeb: Comparative Literature and Culture}

ISSN 1481-4374 <http://docs.lib.purdue.edu/clcweb> Purdue University Press @Purdue University

CLCWeb: Comparative Literature and Culture, the peer-reviewed, full-text, and open-access learned journal in the humanities and social sciences, publishes new scholarship following tenets of the discipline of comparative literature and the field of cultural studies designated as "comparative cultural studies." In addition to the publication of articles, the journal publishes review articles of scholarly books and publishes research material in its Library Series. Publications in the journal are indexed in the Annual Bibliography of English Language and Literature (Chadwyck-Healey), the Arts and Humanities Citation Index (Thomson Reuters ISI), the Humanities Index (Wilson), Humanities International Complete (EBSCO), the International Bibliography of the Modern Language Association of America, and Scopus (Elsevier). The journal is affiliated with the Purdue University Press monograph series of Books in Comparative Cultural Studies. Contact: <clcweb@purdue.edu>

\author{
Volume 17 Issue 3 (September 2015) Article 18 \\ Jane E. Evans, \\ "The Soldier as ' $I$ '-Witness in Novels by Barbusse and Ehni" \\ <http://docs.lib.purdue.edu/clcweb/vol17/iss3/18> \\ Contents of CLCWeb: Comparative Literature and Culture 17.3 (2015) \\ Thematic Issue Life Writing and the Trauma of War. Ed. Louise O. Vasvári and I-Chun Wang \\ <http://docs.lib.purdue.edu/clcweb/vol17/iss3/>
}

Abstract: In her article "The Soldier as 'I'-Witness in Novels by Barbusse and Ehni" Jane E. Evans discusses the representation of the French soldier in two first-person accounts based on life writing journals. The first, set during World War I, describes the simple ground soldier or troufion (Le Feu). The second, set during the Algerian War for Independence and later, sketches the life of the French army conscript. Three themes in Evans's analysis predominate: the narrators' reliance on life writing as sources of inspiration in both Henri Barbusse's 1916 Le Feu and René-Nicolas Ehni's 2002 Algérie roman, the narrator's perception of his role as storyteller and writer including Ehni's idea of the paramyth juxtaposing the individual and the collective whole, and the manner in which the narration is presented through the narrator's point-of-view, format for addressing his audience, imagery, and language style. Evans also considers differences in narrative perspective, attitude, tone, and register in relation to the subjects of war and the soldier, as well as to what they suggest about the narrator's reliability as a witness. 


\section{Jane E. EVANS}

\section{The Soldier as "I"-Witness in Novels by Barbusse and Ehni"}

In this study, I examine two novels marking the early twentieth and twenty-first centuries: Le Feu by Henri Barbusse published in 1916 and Algérie roman by René-Nicolas Ehni published in 2002. Both novels retell men's war experiences, with the first focusing on seventeen members of a French World War I army squadron whereas the second conveys one man's perspective on his military service in the Algerian War forty-seven years later. Although both books offer similar views of the individual's capacity for turning military inspiration into creative works, where narrative objectives and the details of the soldiers' lives are concerned, the novels stand diametrically opposed. The year 2014 marked the one hundredth anniversary of the beginning of World War I in Europe and in order to observe this momentous occasion, European countries planned a wide array of commemorative and educational activities culminating on 11 November in honor of Armistice Day 1918. Across the continent and in the United Kingdom, information about the causes and consequences of the First World War became available through a variety of media, including school curricula, museum exhibitions, television programs, online videos, and published materials such as books and magazines. Additional events have been scheduled for the next four years, until the 28 June 1919 centennial of the signing of the Treaty of Versailles (see, e.g., Foussier <http://aaval.eu/Fichiers/Echanges/Conference-Paris-Berlin-avril-2014.pdf>).

In France, planning for the Great War Centennial began as early as 2012, when the government called for regional participation via meetings with the mayors of towns and cities. It was agreed that the Centennial would cover three main areas, commemorative, historical, and pedagogical, with the last two areas also incorporating the formation of national archives in which to house samples of war memorabilia such as personal objects and talismans, photographs, diaries, sketches, and letters (see Brossé

<http://centenaire.org/sites/default/files/references-files/centenaire bible web double 0.pdf>).

means of such archives, families would have the means of categorizing their loved ones' personal effects for posterity through inventories or even donation via "The Great Inventory" at more than a hundred and fifty different locations across France. As the French government had hoped, the national collection of war writings especially bolstered the publication of first-person samples of life writing including personal diaries, letters, and postcards (see Lemoine <http://www.lagrandecollecte.fr>). Because of the commemorative period underway in France and other European countries and elsewhere, it is also fitting to reread the earliest published French first-person account of World War I, Henri Barbusse's 1916 Le Feu. As a younger man, Barbusse had served in the French Army from 1893-1894 and had published a book of poetry, Les Pleureuses. He had worked as a journalist and a writer of short stories and had even penned a first novel in 1908, L'Enfer, in which the voyeuristic narrator spies on the intimate aspects of his neighbors' lives. Barbusse frequented literary salons in Paris in the early 1900s but when the "Great War" began in 1914, he enlisted in the French Army as a forty-one year old. Believing in the power of observation, he kept notes on the daily activities he witnessed at the Western Front and shared anecdotes and thoughts about military life through letters written to his wife, first published in 1937 and re-issued in 2006 as a reminder of Barbusse's double contribution to life writing. He was hospitalized three times during his military service from 1914 to the end of 1915, when he was moved to an office job because of pulmonary damage and other health concerns (see Hertz

<http://babel.hathitrust.org/cgi/pt?id=njp.32101063575573; view=1up;seq=52>).

Le Feu, which first appeared in installments as Journal d'une escouade in the Parisian newspaper L'Oeuvre in 1916, was published as a book in that same year and was awarded the Prix Goncourt (see, e.g., Gengembre

<http://www.culture-cpge.com/la-guerre/henri-barbusse-le-feu-resume-et-commentaire>). In Le Feu the first-person narrator, Barbusse himself, dedicates his novel to all his fellow soldiers in the 119 th Squadron fallen from injuries, illness, and death next to him in Crouy. From the beginning of the text he therefore speaks as one of them, supposedly relying on the journal he kept during his seventeen months of military service in order to recall events and dialogues among the men. As narrator, he characterizes himself the least, devoting his attention instead to the lives of thirteen soldiers, fictionalized representatives from different backgrounds and regions, among whom are: Pépin, profession and region unknown, killed during the attack; Tulacque, bistro owner from the Paris area, evacuated due to pneumonia; Betrand, the squadron's corporal and manager in a clothing factory, killed; Eudore, owner of a small café in a northern French village, killed while on a reconnaissance mission; Poterloo, miner from the northern town of Souchez, France and victim of a fatal explosion; Caron, evacuated because of an injured arm; Joseph Ménil, seller of books and periodicals, injured; his brother André Ménil, salesman from Normandy, killed while on reconnaissance; and Volpatte, who sustains severe ear injuries, but returns to his regiment. Hailing from various geographic locations, the narrator's peers represent a cross-section of the French population and its livelihood during the second decade of the twentieth century. Moreover, their various fates from 1914 to 1916 attest to the divergent personal consequences of the war years, with death being the most prevalent.

The squadron's geographic and professional diversity are but two aspects of the realism that imbues Le Feu. Another true-to-life element concerns the soldiers' different ways of speaking the French language, resulting from their divergent mastery of it as well as their regional accents and patois, which the narrator captures to the best of his ability. For example, Tirette boasts to the others that he is from Clichy-la Garenne, and challenges his fellow soldiers to be from anywhere better. His use of 
the expression, "lads," "mes enfants," characterizes his facility with the French language and condescension towards the others. Another soldier, Paradis, murmurs ungrammatically in reply that Tirette was making fun of him because of his eastern origins (see Le Feu 18; Under Fire 15). Paradis's response indicates his awareness of Tirette's superior attitude, as well as his own rudimentary French perhaps resulting from his lack of education or practice in the standard language or both. If the narrator stresses the regional and class distinctions among his fellow soldiers, he nevertheless insists on their commonalities as troufions (Barbusse 27) or simple ground soldiers engaged in trench warfare. He explains that he and his fellow soldiers have overcome their linguistic differences by adopting a "mixture of workplace and barrack slangs ... peppered with a few neologisms" that blends them together, as "a sauce" more delicious than its individual ingredients (Le Feu 19; Under Fire 17). The narrator's account of the synergy that diverse Frenchmen achieved in fighting a common enemy exemplifies that 1914-18 were crucial years in the development of French nationalism (see Weber 485). When local military units were decimated and then restructured, soldiers were forced to speak French as a lingua franca to ensure communication between the men (see Weber 78).

The first-person narrator of Le Feu subsumes his individuality in the collective whole of the regiment: the subject pronoun "je" appears only about thirty times in the 378-page novel. Most often, the narrator uses the first person plural subject pronoun "nous" indicating his solidarity with his fellow conscripts, or he opts for the third person singular subject pronoun "on" in order to generalize. The novel contains only one chapter, "Les Gros Mots," in which the narrator comments to a fellow soldier on his role as witness and writer of the squadron's life experiences. Barque, a fellow Parisian, watches him write and then confronts him about making the account reflect the soldiers' coarse language. To Barque's contentment, the narrator agrees that keeping his story truthful about the soldiers' existence is his major preoccupation, despite publication difficulties that he might face subsequently. The narrator's apprehensions regarding the publication of his novel were unfounded, however: readers devoured Le Feu which sold more than 250,000 copies by the end of the war and was considered a bestseller by Flammarion, its publisher (see Johnson and Johnson 155). According to historian Nicolas Offenstadt, even today's French people are obsessed with life in the trenches during World War I, especially how the soldiers tolerated the primitive living conditions, as well as the "colossal suffering" of combat). In the Preface to a special 1917 edition of his novel, Barbusse himself declares that he will help his peers keep the memory alive of their "hell" and "monstrous and disgusting horror of war" (see Gegenbre, "Henri Barbusse" <http://www.culture-cpge.com/la-guerre/henri-barbusse-le-feu-resumeet commentaire $>$ ). With this preface in addition to the novel's graphic descriptions of war casualties, Barbusse's Le Feu was seen by many as a pacifist's cry that downplayed military heroism and its 1916 Prix Goncourt literary prize an outrage (see Johnson and Johnson 155).

Later scholars would re-open the subject of Le Feu's qualities when Les Carnets de guerre de Louis Barthas, tonnelier, 1914-1918 was published in 1978. Barthas, who had worked in the infantry with his men for most of his military service in the French Army, had miraculously escaped any injury whatsoever. He meticulously recorded the activities of his fellow soldiers and himself in nineteen notebooks that he always carried, which amounted to over 1,700 handwritten pages. Corporal Barthas's account of his experiences in the trenches at the major battle sites during four years at the front was to become a more than 500-page book. Here, then, was the true model of military life writing: through the inclusion of letters written and received, his own journal entries, cartoons and drawings, and some photographs, Barthas demonstrated various dimensions of his personality, as well as an awareness of his diverse readership. Unlike Barbusse who was a well-educated published poet and novelist, Barthas possessed a mere elementary school education (see Cazals 5) and Barthas claimed that his sincerity in narrating his story was his dominant feature, although French President Mitterand praised Barthas's work for its historical and literary value (see Cazals 554). Not only did Le Feu disappoint some of its readers because of its down-to-earth qualities, it also followed a format not previously seen in the classic war novels culminating in the defeat of the enemy. Traditionally, the combat narrative abounded with expressions designating the soldiers' courage and its author kept precise details about wounds and suffering to a minimum (see Cobley 57). Barbusse's account of the "Great War," in contrast, underscores the humanity and physical vulnerability of all soldiers, regardless of nationality. For instance, his first mention of soldiers of any kind refers to them as "shadows" emerging from the trenches (Under Fire 5) and then reiterates immediately that the soldiers are "human" (7). He comments similarly that under the men's rough exterior, their hearts speak to them of cozier times with loved ones (Under Fire 44). The use of "hearts," a synecdoche designating entire soldiers by their emotional center, reminds the readers that the men are sensitive individuals rather than killing machines. But the most poignant depiction of French and German conscripts alike occurs at the end of the novel following a strong rain in which many drowned during the night. In this apocalyptic vision, trenches have been washed away and all the dead or sleeping soldiers, covered with a layer of mud, have lost any distinguishing characteristics among them, such as the color of their uniform or the make of their weapon. And yet the narrator calls them "men" repeatedly, out of respect for their untimely suffering, if not death (Under Fire 350-55).

The narrator reiterates the human aspect of his fellow French soldiers in elaborating that the war was nothing in which the soldiers chose to participate; rather, it was imposed on them. He elaborates this point by referring to the squad members as "civilians uprooted" (Wray 241). In emphasizing the soldiers' lives as ordinary, productive working-class citizens, the narrator ennobles their sacrifices in battle, calling their service "that sort of madman's part imposed on all men by the madness of the human race" (Under Fire 243). For him, war and its killing symbolize the mental illness that is endemic to all societies, and this compassionate perspective grows keener as the text progresses. His description of characters who exhibit an increasing self-awareness as the war continues reinforces the "human" aspect of military service too. For instance, Volpatte returns willingly to his squad following 
two months' convalescence in a military hospital because of injuries and unburdens himself to his fellow troufions of the inequalities that he observed in the military services that other Frenchmen fulfill. He rages that the rich perform office jobs instead of engaging in battle as he and other poor soldiers have done repeatedly in order to contribute to the war effort (Under Fire 120-38) thereby displaying for the first time his cognizance of the quality of life that money can buy.

Just as Volpatte decries the inequalities that he witnessed while a hospitalized convalescent to the men of his squadron, Poterloo, a fellow soldier from the north, confesses to the narrator in emotionally charged speech what really happened when he saw his wife during his last visit home: not only were they unable to meet as planned, he glimpsed her seated between two German sub-officers at her parents' house, and she was smiling. At the culmination of his story, Poterloo's short sentences belie his deepest insecurity as follows: "She's quite young, you know; she's twenty-six. She can't hold her youth in ... It's life. She lives" (Under Fire 158-59). Poterloo's account thus verbalizes the soldiers' very real fear of having an unfaithful or endangered spouse at home while they are engaged in combat at the front. In essence, Le Feu provides a multifaceted view of the French soldier's life during the First World War. Barbusse's observations of his comrades in battle and his recall of conversations among them cast the men in a naturalistic light: their daily sufferings during trench warfare, the war as a death machine, the philosophies that strengthen the men in combat, civilian misconceptions about the front, the similarity between men regardless of nationality, all are included here. He proves himself to be an astute observer of the events around him and an excellent listener to the men who pour out their hearts to him, including Volpatte and Poterloo, whose stories animate the narrator's account of war in Le Feu. Inasmuch as Barbusse's writing about the effects of war on men displays verisimilitude, his narrative stance strikes the reader as unrealistic. However meticulously he may have kept his personal journal, he would not have recorded events simultaneously as they happened: the narrator as a soldier had to fulfill his own duties in combat. At best, Barbusse would have had to reconstruct incidents after they occurred and recall the contents of dialogues to the best of his ability. Thus, the double classification of Le Feu as a first-person account and a novel that Barbusse himself bestowed on this book captures both its witnessing to the truth about trench warfare during the First World War and Barbusse's creativity in retelling the events.

Twentieth-first century critics and scholars of the novel have reconsidered the issue of genre, and posited that the best term for Le Feu is "chronicle" because of its portrayal of fictionalized characters facing authentic historical events as they actually occurred. They also criticized the extent to which Barbusse homogenized the soldiers' war experiences. Today's psychological terminology associated with war, such as post-traumatic stress disorder can also be applied to Barbusse's novel of his fellow soldiers' experiences. The narrator escorts mentally fatigued men to the clinic within earshot of the front, for example, so that they remain aware of the fighting and anticipate rejoining their squadron. Such detail acknowledges the author's awareness of early twentieth-century treatment ideas for the treatment of shell shock, also known as "soldier's neurosis" (see, e.g., Crocq and Crocq). Frederick W. Mott, for example, studied the cases of hundreds of wounded British and French First World War soldiers in a London convalescent hospital and advocated subsequently that patients facing mental challenges such as nightmares and paranoia from the war be rehabilitated through electro-shock, reeducation, and discipline (xiii-xvi). Mott's contemporary, W.H.R. Rivers, however, promoted the complete reverse of the former's recommendations. In a 1917 speech, Rivers argued for the "cessation" of the repression of painful war memories because of his outstanding results with soldiers who had been permitted to relive their war experiences in cognitive therapy sessions with him

(<http://net.lib.byu.edu/ estu/wwi/comment/rivers.htm>).

Both Barbusse as author and his narrator in the same capacity witness to the testimonies heard in the war zone. According to Shoshana Felman and Dori Laub, Holocaust specialists whose research has retroactive applications to First World War survivors, through the process of turning lived experiences into a narrative form, both writerly figures engage in "re-externalizing the event" and grieve. Rivers had already seen this in the earlier twentieth century when his war veteran patients overcame their traumatic experiences by verbalizing them. Only through the process of articulating the event and transmitting it as a story can one avoid being entrapped by the same traumatic circumstances that one is writing about (Laub, "Bearing" 69; Rivers

<http://net.lib.byu.edu/estu/wwi/comment/rivers.htm>). By sharing his account, the narrator reasserts "the veracity of the past" and allows his witnessing to be witnessed: this is the third level of witnessing, namely making the testimony public (Laub, "Event" 76). Paradoxically, Barbusse's narrator, in assuming the role of "I"-witness, practices self-effacement, meaning that his life writing stance excludes his own personal experiences as he relates what he saw and heard in combat so that his account will supposedly be more authentic (see Cobley 76-77). As in the last century, the issue of witnessing to trauma has been taken up many times by contemporary scholars, including Yuval $\mathrm{N}$. Harari. In his "Scholars, Eyewitnesses and Flesh-witnesses of War: A Tense Relationship," he discusses the role of the three people mentioned above. The "eyewitness" remains at a distance from the war while recording its events and relies on the "scholar" to process his/her data according to Harari, whereas the "flesh-witness," who has personal experience of the events and perhaps even serious injuries, carries the most authority of the three. However, it is the "flesh-witness," by being caught in the midst of the devastating action, that is the least likely to be able to convey this experience to the eyewitness, and ultimately, the scholar for processing (218-220). In Harari's terms, then, Barbusse as a limited "flesh-witness" would make a more capable "eyewitness."

Like Barbusse's novel based on observations recorded in his personal journal, Ehni's 2002 autobiographical novel, Algérie roman refers to the narrator's life-writing in notebooks during the Algerian War for Independence as its source of inspiration. The two works differ in their public reception, however, with the year 2014 marking the well commemorated centennial of the First World War in Europe, 
and the almost forgotten $60^{\text {th }}$ anniversary of the beginning of the Algerian War for Independence. The latter received only 18 seconds of air time via actual war footage in the news broadcasts in France, although it was commemorated solemnly in Algeria, France's former colony. Unlike Barbusse's narrator, who states his commitment to telling the truth about his fellow soldiers experiences in the dedication to Le Feu, Ehni dedicates his novel to Pierre-André Boutang, his best friend (see Loret <http://www.liberation.fr/livres/2000/01/13/ le pope-club-de-rene-nicolas-ehni 314669>). Ehni was born in Alsace into a Jewish working class family, spoke Alsatian and later learned French, German, and Greek. He has been known as a controversial social figure, critic, and writer for the past fifty years with life experiences ranging from acting in Paris theater to completing two and a half years of military service in Algeria. Following his military service, Ehni frequented artistic circles, became the "pet" of a rich widow, and had a three-year love affair with choreographer Maurice Béjart after the latter had seen him dancing naked in the moonlight. Ehni counted Simone de Beauvoir, who had highly praised his first novel, as well as his dramatic plays, among his literary acquaintances and friends and although known as the enfant terrible through the 1960 s and into the 1970s, Ehni subsequently disappeared from the public eye. He published only two novels in the 1980s, a period during which he converted to Greek orthodoxy, married, and had two children (see Lindecker

<http://libresdedire.blogspot.com/2012 /08/eschentzwiller-le-paradis-perdu-de-rene.html>. Since then, he has continued to fill notebooks with his fiery outbursts on politics, poetics, and spirituality just as he did as a young soldier fulfilling his military duty. In Algérie roman he narrates his wartime experiences through a series of disconnected episodes from both civilian and military life which explain his reason for converting to Christianity (see Rosello, "René-Nicolas" 76). His intermittent narration of the Algerian War runs counter to the collective, authoritative, and chronological model encountered in Barbusse's Le Feu. The tropes and figures in Algérie roman demonstrate Ehni's violent, irreverent stance as a young soldier in his early 20 s and as a mature adult storyteller later recalling his military service by means of a "paramyth," or a myth in its "most powerful" version.

Despite Ehni's lack of a clear definition for paramyth, some critics and scholars including Denton $\mathrm{J}$. Snider, Mireille Rosello, and Isidore Okpewho have elaborated on the term. Snider states that the paramyth "rebuilds" the myth by injecting new meaning into it, whereas Rosello insists that the prefix "para-" indicates the coexistence of two entities, the myth and its reinterpretation. Thus Ehni is not asking the reader to replace familiar myths which speak to a community of people, but to allow his texts to exist "side by side with other narratives that he does not wish to erase" (88). Isidore Okpewho concurs with Rosello in explaining that the paramyth is a philosophical concept, a moral allegory, a symbol seized upon, cut off from the living whole "to see one form in the whole to the exclusion of the others is to see a paramyth" (219). The reader can thus surmise that Ehni will provide an unconventional account of his military service in Algeria. Indeed, the first page of Algérie roman consists of one long paragraph in which the narrator speaks about himself and his family: he is young (the reader learns later that he is twelve years old), he has a papa who served in the Algerian War (9), and his father also belonged to the group of French soldiers who kept the narrator's Algerian grandfather prisoner before killing him. The reader also learns that many years after the close of the Algerian War the narrator's male parent found the dead prisoner's daughter and married her. Along with being shocked at the composition of the narrator's family, the reader perceives that this young narrative voice will not be a reliable speaker about his father's war experiences because he was not there nor could he possibly know everything about his parent's former life even from the stories he may have heard.

From its opening, then, Algérie roman calls narrative authority into question through its inclusion of a child narrator. The reader's doubts about narrative credibility continue on the second page of the novel as an older voice resumes the storytelling, but only to posit the idea of the paramyth, rather than the previously mentioned family relationships. Moreover, the older narrator expresses himself in French, Greek, and German with equal facility. For example, he uses the Greek word for "family," comments on the derivation of the French mythe from Greek, and refers to his own grandfather with the Swiss German word gräbi (10), a confusing play of language for the reader who nevertheless understands that this information about Ehni's family is meant to accompany the account of the narrator's military service. Unlike Le Feu, whose single narrator comments on the soldiers' neologisms as a way to override regional linguistic differences, Algérie roman presents the narrator's preoccupation with word etymologies within the context of his own family interests. Not until the third paragraph does the storyline set during the Algerian War of the 1950s appear with an adult narrator as the soldier in situ. Here is the papa mentioned in the child narrator's opening words, which illustrates the destabilization of the narration through several levels known as metalepsis (see Heise 55). Such a technique establishes an irresolvable narrative tension, in that the narrative voices of the child, the young soldier and the older version of himself will never coincide on the account of the Algerian War. The older René cannot recreate the younger René's experiences completely; nor can he recall everything that the latter had excluded from his wartime journal in the 1950s. Whereas Barbusse's Le Feu presents 55 days of its narrator's 17-month military service chronologically, Algérie roman assembles events linked by image and/or theme rather than by linear time. Ehni's reader understands that the narrative voices of the novel, which vary because of age and expertise on the subject of the father's military experience, are not necessarily complementary. The narrators depart from the storyline about the Algerian War for the purpose of making genealogical, judgmental, etymological, linguistic, and literary remarks. The reader thus sees the text as "a contradictory site of inscription" and its events as both diachronous and synchronous, meaning that "the horizontal or sequential movement of the plot thus coexists with the vertical or associative stratification of temporally discontinuous fragments" (see Cobley 3, 190). As mentioned above, the young adult and middle-aged narrators in the novel witness to different elements of the Algerian War. For instance, the younger René focuses on his entertain- 
ment prior to military service, such as when he and a friend played tricks on three homosexual men. It is the elder René who contemplates the horror of having to fight "enemy" Algerians who had defended France during the Second World War. Only when the narrator returns to an incident several times, like the 1958 murder of two young Algerian shepherds or the death of Aïssa, the Algerian prisoner of war, does the reader grasp the entire meaning of the event, as well as the storyteller's revulsion in sharing his memories.

Despite the initial confusion about which narrator is speaking and the significance of his account, the reader comprehends that the middle-aged René is transcribing his diary from the 1950 s in order to compose the text. However, when remembering an emotionally-charged event overwhelms him, he interrupts the diegesis, such as when he details his acting experience in Paris and an etymological analysis suggesting his gypsy origins in order to provide a detour from talking about his grandfather's disapproval of his going to war (10-12). In contrast to the narrator of Le Feu who plunges into the authoritative retelling of his squadron's experiences as part of the image of the soldier intent on speaking of his peers' bravery, Ehni's narrators reveal little about their quotidian military duties. Not until the middle two chapters, for example, does the reader acquire a minimal understanding of the young adult narrator René's responsibilities as a soldier in an Algerian village. Poetic lines in German by Goethe, as well as René's French translations divert the narrator's and the reader's attention from the horrors of the war. The footnotes given by the elder narrator to clarify the Algerian's status under French law, the contents of the prayer, "Ma chère Maman" and the meaning of the acronym "HS" (Hors de service) $(74,89-90,93)$, further delay the elder narrator and the reader in examining the contents of the soldier René's diary and further obscure the young man's duties and courage or cowardice. In a later example, René the elder disturbs his narration of the war once again by digressing about a song in German and French, as well his "Teutonic soul" (125), which postpones for the third time the account of the death of two Algerian child shepherds at the hands of his commanding officer.

By deferring information about the children's deaths repeatedly, the older narrator protects himself from excavating tragic memories of the past and even criticizes his writing of Algérie roman as it unfolds. For instance, after describing his flight to Marseille with Dino, a friend, René the elder instructs his editor parenthetically to omit a vulgar sentence about the friend that he has not yet written (23). The technique of occupatio or seemingly discounting an idea, in this case, Dino's homosexual practices, in fact emphasizes that very idea. The discussion of his friend's sexuality, as well as his own narrative hesitation about what to say contrasts with the confidence of Barbusse's "I"-witness who limits himself to describing living conditions and soldier solidarity during the First World War. René the elder as narrator comments similarly that five vulgar lines about the male sexual organ are to be omitted from an unpublicized story concerning Dino (30-31). Expressing his subsequent unease about what he has just shared merely calls attention to his attraction to Dino. At the very least, the narrator's editorial remarks underscore the selective aspect of writing his memoirs, while they also suggest playfulness towards the novel's composition, an element absent from Le Feu. Further, overblown emoting on the part of its narrators likewise makes Algérie roman ambiguous. In relating the suffering associated with their reminiscences about the Algerian War, the narrators rely on threnos (lamentation). For example, the two René-s concur on writing tearfully about leaving their grandfather just before reporting for military service (12-13). In the same way, the younger René indicates in a letter to his mother how much he dislikes writing, but how he must continue with this "too painful" activity (36). The reader is struck again by the narrator's pose as he claims to cry, a position so unlike that of Barbusse's narrator in Le Feu who exhibits virtual immunity to the emotional stressors of fighting and writing. The elder René reiterates the writer's pain in referring to the atrocities that he and his fellow soldiers committed. As he puts it, writing about the Algerian War implies the same violence as suicide or selfdestruction (72-73), which could mean that revisiting one's memories involves re-acknowledging one's younger self, a person who has "died" in the process of maturation and aging. Ehni's dramatic narrator pales in comparison with Barbusse's raconteur who bravely details trench warfare without dwelling on his own suffering as a participant in the war or as an author.

If Ehni's narrators de-emphasize their physical involvement in the war through the figures of digression, occupatio, and lamentation, they also use synecdoche for diminishing their army commanders who engage in killing for sport. The officers in question have nicknames designating the entire person by a single body part, to wit the male sexual organ, and are never known as anything other than "Bout'bite" ("Penis Head") (62), "Sucepine" ("Performer of Fellatio") (36), and "Quéquette" ("Little Penis") (61). By referring to their superiors using vulgar terms, the narrators reduce the officers to brainless, testosterone-fueled creatures, from which excessive murder is expected (see Accad 16061). The contrast between the commanders' funny nicknames and their ruthless killing of Algerian villagers adds an ironic twist to the narrative, a dimension absent from Barbusse's chronicle. paronomasia (word play) in Algérie roman further designates the narrators' manipulation of the reader. For example, the older René declares, "Paris vaut bien un macule" (17) before he includes information about living in the French capital. The misquoting of the well-known "Paris vaut bien une messe" jars the reader, who wonders about the narrator's purpose in equating his description of Paris with ink blotches. Likewise, the narrator's use of homonyms makes his discussion of war's mental trauma ironic, such as when he refers to the postwar need for psychoanalysis as "ma tasse de thé, thé au logis" (51). The double entendre of "tea at home" and "theology," which are pronounced identically in French, problematizes the narrator's attitude for the reader as the idea of regaining one's mental health post-bellum by drinking tea at home (instead of studying God), appears simplistic and playful through the repetition of the syllable, thé, if not mocking. Despite the elder narrator René's comments about being able "to mold" his wartime pages into the novel (19), his reducing the seriousness of his two-year army service through narrative unreliability, metalepsis, digression, occupatio, paronomasia, synecdoche, and irony almost obscures his condemnation of both the Algerian War and the French 
Army. Ehni's elder narrator criticizes the pro-independence political party, the FLN (Front de Libération Nationale) in particular for pitting innocent civilians against the French military presence. He also denigrates the French Army's reliance on torture for gathering information from Algerian prisoners, as well as their later denial of this cruel practice (58-60, 61-69). The emphasis on war's destructive nature echoes the condemnation of war by Barbusse's pacific narrator.

René the Elder's vocabulary play falters, however, as he revisits an incident pertaining to Aïssa, Arabic for Jesus, an Algerian prisoner of war. He confesses to being awestruck at seeing "the face of the Archetype" in the Semite's and subsequently describes his meeting with Aïssa as "la rencontre avec mon Dieu" (155). Gone is his poseur's attitude as the elder Rene demonstrates his ability to write linearly and chronologically, stylistic changes which bear witness to the transformation within him. Typically so prolix, he concludes the novel by identifying the terror that he experienced before God and by running out of things to say. Because of the narrator René's encounter with his God whom he kills despite repeatedly recalling the commandment, "Thou shalt not kill" (11 et passim), Rosello argues that Algérie roman focuses on the narrator's epiphany of recognizing Jesus Christ in the enemy prisoner Aïssa, rather than on the disjointed account of a young soldier's experiences in the Algerian War. According to Rosello, Ehni, who identified as a Jew his whole life, converted to Orthodox Catholicism owing to his meeting with Aïssa ("René-Nicolas" 76). Rosello also reads the novel as a statement on "the ever-changing quality of what we call cultural memory" ("A Literature" 175), an idea with applications to the novel's younger and elder narrators. Only since June of 1999 has France admitted that the Algerian événements and "actions de maintien de l'ordre," among other euphemisms, were indeed a war (Donadey 17), and, one could add, worthy of being discussed in speech and writing. Hence, Ehni's two René-s would understandably falter in assigning a historical and personal value to their military experiences. The pre- and post-1999 confusion associated with the Algerian "events" contrasts sharply with the wide-spread public attitude that the First World War deserves commemoration.

In contrast to Le Feu whose narrator witnesses to the truth of First World War experiences for his fellow soldiers, history, and himself (in that order), Algérie roman maintains a scattered, self-absorbed narrator until its final page. The latter, incapable of characterizing his military service in Algeria coherently owing to his immaturity while a young soldier and his emotionality as a middle-aged veteran revisiting war memories centered on his guilt as the murderer of "Jesus" (Aïssa) and his consequent religious epiphany, remains fixated on his personal story dominated by the deaths of two shepherd children and the enemy prisoner. If Barbusse's Le Feu conveys a message of pacifism in its final chapter on the devastation caused by the First World War, Ehni's novel continues its quest for closure even after its final sentence: "Il s'ensuivit une errance" (156). Although the ellipses visually carry the reader forward, the simple past tense verb, "s'ensuivit" refers the reader back to the narrative account that has seemingly just come to an end.

\section{Works Cited}

Accad, Evelyne. Sexuality and War: Literary Masks of the Middle East. New York: New York UP, 1990.

Barbusse, Henri. Le Feu, Journal d'une escouade. Paris: Flammarion, 1916.

Barbusse, Henri. Under Fire. Trans. Fitzwater Wray. London: Dent, 1926.

Barthas, Louis. Les Carnets de guerre de Louis Barthas, tonnelier, 1914-1918. Paris: La Découverte, 2013.

Brossé, Aurélien, ed. 2014 Centenaire de la Première Guerre Mondiale. centenaire.org (2014): $<$ http://centenaire.org/sites/default/files/references-files/centenaire bible web double 0.pdf >

Cazals, Rémy. "Préface à l'édition du centenaire, Louis Barthas et son manuscrit." Lés Carnēts de guerre de Louis Barthas, tonnelier, 1914-1918. By Louis Barthas. Paris: La Découverte, 2013. 5-8.

Cobley, Evelyn. Representing War: Form and Ideology in First World War Narratives. Toronto: $\mathrm{U}$ of Toronto $\mathrm{P}$, 1993.

Crocq, Marc-Antoine, and Louis Crocq. "From Shell Shock and War Neurosis to Posttraumatic Stress Disorder: a History of Psychotraumatology." Dialogues in Clinical Neroscience 2.1 (2000): 47-55.

Donadey, Anne. Recasting Postcolonialism: Women Writing Between Worlds. Portsmouth: Heinemann, 2001.

Ehni, René-Nicolas. Algérie roman. Paris: Denoël, 2002.

Felman, Shoshana, and Dori Laub. Testimony: Crises in Witnessing in Literature, Psychoanalysis, and History. New York: Routledge, 1992.

Foussier, Gérard. "Europe. Le Désamour avant le mariage de raison? Paris et Berlin à la recherche d'une nouvelle vocation européenne." aaval.eu (2014): <http://aaval.eu/Fichiers/Echanges/Conference-Paris-Berlin-avril2014.pdf>.

Gengembre, Gérard. "Henri Barbusse, Le Feu. Résumé et commentaire." culture-cpge.com (n.d.):

<http://www.culture-cpge.com/la-guerre/henri-barbusse-le-feu-resume-et-commentaire>.

Harari, Yuval N. "Scholars, Eyewitnesses, and "Flesh-witnesses of War: a Tense Relationship." Partial Answers 7 (2009): 213-28.

Heise, Ursula K. Chronoschisms: Time, Narrative, and Postmodernism. Cambridge: Cambridge UP, 1997.

Hertz, Henri. Henri Barbusse, Son Oeuvre: Etude critique. Paris: Carnet-Critique, 1920.

Johnson, Claudia D., and Vernon Johnson. The Social Impact of the Novel: A Reference Guide. Santa Barbara: Greenwood, 2002 .

Laub, Dori. "Bearing Witness or the Vicissitudes of Listening." Testimony: Crises in Witnessing in Literature, Psychoanalysis, and History. By Shoshana Felman and Dori Laub. London: Routledge, 1992. 57-74.

Laub, Dori. "An Event without a Witness: Truth, Testimony and Survival." Testimony: Crises in Witnessing in Literature, Psychoanalysis, and History. By Shoshana Felman and Dori Laub. London: Routledge, 1992. 75-92.

Lemoine, Hervé, ed. "La Grande Collecte: les 14 et 15 novembre 2014" ("The Great Collection: November 14 and 15, 2014") Paris: Bibliothèque Nationale de France: 2013; < http: //www. lagrandecollecte.fr >.

Lindecker, Jacques. "Eschentzwiller, le paradis perdu de René-Nicolas Ehni." ("Eschentzwiller, the Lost Paradise of René-Nicolas Ehni") libresdelire.blogspot.com (3 August 2012): <http://libresdelire.blogspot.com/2012/08/eschentzwiller-le-paradis-perdu-de-rene.html>. 
Loret, Eric. "Le Pope club de René-Nicolas Ehni." Libération.fr (13 January 2000): <http://www.liberation.fr/livres/2000/01/13/le-pope-club-de-rene-nicolas-ehni 314669>

Mott, Frederick Walker. War Neuroses and Shell Shock. London: Frowde, Hodder\&Stoughton, 1919.

Okpewho, Isidore. Myth in Africa. Cambridge: Cambridge UP, 1983.

Rivers, W.H.R. "The Repression of War Experience." The Lancet (2 February 1918) 1-11.

Rosello, Mireille. "A Literature without a Name." Memory, Empire, and Postcolonialism: Legacies of French Colonialism. Ed. Alec G. Hargreaves. Lanham: Lexington Books, 2005. 174-86.

Rosello, Mireille. "René-Nicolas Ehni: Matricide and Deicide as Figures of Unforgivable Violence and Redemption during the Algerian War for Independence." The Reparative in Narratives: Works of Mourning in Progress. By Mireille Rosello. Liverpool: Liverpool UP, 2010. 63-100.

Rosello, Mireille. The Reparative in Narratives: Works of Mourning in Progress. Liverpool: Liverpool UP, 2010.

Snider, Denton J. Goethe's Faust: A Commentary, Part 2. St. Louis: Sigma Publishing, 1886:

Weber, Eugen. Peasants into Frenchmen: The Modernization of Rural France, 1870-1914. Stanford: Stanford UP, 1976.

Author profile: Jane E. Evans teaches French-language literature at the University of Texas, El Paso. Her interests in scholarship include twentieth- and twentyfirst-century French and Francophone novels and autobiography. Evans's publications include "Memory as Performance: Fatima Gallaire's Molly des Sables and Rimm la Gazelle," Women in French Studies (2014), "Autobiography as Metaphrasis: Malika Mokeddem's La Transe des insoumis," Life Writing (2013), and the book Tactical Silence in the Novels of Malika Mokeddem (2010).

E-mail: <jeevans@utep.edu> 